\title{
Discretion in Bank Loan Loss Allowance, Risk Taking, and Earnings Management
}

\author{
Justin Jin \\ DeGroote School of Business \\ McMaster University \\ E-mail: jinjus@mcmaster.ca \\ Kiridaran Kanagaretnam \\ Schulich School of Business \\ York University \\ E-mail: KKanagaretnam@schulich.yorku.ca
}

\author{
Gerald J. Lobo \\ C. T. Bauer College of Business \\ University of Houston \\ E-mail: gjlobo@uh.edu
}

November 10, 2015

Jin thanks the DeGroote School of Business for its financial support. Jin, Kanagaretnam and Lobo thank the Social Sciences and Humanities Research Council of Canada (SSHRC) for its financial support. 


\title{
Discretion in Bank Loan Loss Allowance, Risk Taking, and Earnings Management
}

\begin{abstract}
We study whether bank managers' use their discretion in estimating the allowance for loan losses (ALL) for efficiency or for opportunistic reasons. We do so by examining whether the use of this discretion relates to bank stability and bank risk taking, or whether it relates to earnings management to meet or beat earnings benchmarks. We find that banks that had higher abnormal ALL during the period prior to the 2007-2009 financial crisis engaged in less risk taking during the pre-crisis period and had a lower probability of failure during the crisis period. In tests related to earnings management to meet or beat earnings benchmarks, we find that abnormal ALL is unrelated to next period's loss avoidance and just meeting or beating the prior year's earnings. Our results suggest that bank managers use their discretion over ALL for efficiency and not for opportunistic purposes. They inform policy makers and accounting standard setters on banks' use of accounting discretion as a means to build a cushion against future credit losses as they transition from the incurred loss model to the expected loss model for loan loss accounting.
\end{abstract}

Keywords: Loan Loss Allowance; Risk Taking; Financial Crisis; Earnings Management

JEL classification: G14, G21, M41, and M42 


\section{Discretion in Bank Loan Loss Allowance, Risk Taking, and Earnings Management}

\section{Introduction}

We examine whether bank managers' use of discretion in estimating the allowance for loan losses relates to bank risk taking, performance, and earnings management for a sample of U.S. banks. ${ }^{1}$ The allowance for loan losses (ALL) offers an appealing context for studying the implications of managerial discretion in the banking industry as it accounts for a significant percentage of a bank's equity (approximately $10 \%$ for our sample of banks) and acts as a buffer against credit losses during bad economic times. Loan loss provisioning practices in general, and loan loss reserves in particular, have been controversial and are constantly scrutinized by regulators and accounting standard setters. For example, in 1994, the U.S. General Accounting Office (GAO) sharply criticized the banking industry for its loan loss accounting practices, claiming that reserves for loan losses could not be meaningfully compared because they were developed using methods that varied greatly in terms of the assessment of individual loans, the application of historical loss experience, and the inclusion of "supplemental” reserves not clearly linked to loan losses. These and other observations resulted in the Financial Accounting Standards Board (FASB) adopting and amending FAS 5, FAS 15, and FAS 114 to incorporate the incurred loss model for loan loss provisioning.

However, more recently, the focus of bank provisioning practices has shifted abruptly, partly in response to the perceived failure of banks, prior to the 2007-2009 financial crisis, to anticipate losses not necessarily identifiable from current loss exposures (Dahl 2013). The Financial Stability Forum (FSF 2009) recommended that bankers be given more latitude to exercise "reasonable judgments" in establishing provisions. The U.S. Treasury (2009) similarly

\footnotetext{
${ }^{1}$ We use the terms loan loss reserves and loan loss allowance interchangeably throughout the paper.
} 
recommended that provisioning "incorporate a broader range of available credit information" and be more "forward-looking.” The FASB (2011), in an apparent reversal of its earlier position, concurred with the proposed standards for loan loss provisioning incorporating expected losses, as did the Basel Committee on Banking Supervision (BCBS 2011) and the International Accounting Standards Board (IASB 2011).

Prior research documents that even the current incurred loss model of provisioning for loan losses provides some latitude for managerial discretion in estimating loan loss provisions and loan loss reserves. ${ }^{2}$ Ryan (2011) notes that loan officers have discretion in estimating credit losses for individually large heterogeneous loans whereas they can exercise relatively less discretion in estimating credit losses for homogenous loans, such as credit card loans, where credit losses are generally determined by statistical methods. Given this evidence, we exploit the cross-sectional differences in loan loss provisioning practices to compute abnormal ALL after controlling for the determinants of normal ALL and then use these abnormal ALL amounts as a proxy for managers' use of discretion.

We argue that abnormal ALL relates to pre-crisis-period risk taking and crisis-period performance. Conservative loan loss allowance practices could have a direct impact on lending behavior, loan volumes, and selection of borrowers, thus leading loan officers, who have to meet profitability targets (net of loan loss provisions), to be more selective in their lending decisions. In addition, the timely recognition of credit losses and the building of reserves to cover potential future losses will directly affect profitability and capital ratios, which will likely constrain growth in risky loan portfolios during credit expansion periods. Moreover, we expect banks that

\footnotetext{
${ }^{2}$ Prior research suggests several motives for bank managers' discretionary behavior with respect to LLP, including signaling, capital management, management compensation, and income smoothing (Wahlen 1994; Collins et al. 1995; Kanagaretnam et al. 2004; Cheng et al. 2011).
} 
are more conservative in their loan loss accounting to have a lower likelihood of failure during a financial crisis because of lower risk taking prior to the crisis as well as because they have a larger cushion against which to write off their loan losses during the crisis.

According to Bushman and Williams (2012), accounting discretion cuts both ways. Whereas, on the one hand, increased discretion can be used to incorporate information on future expected losses, on the other hand, it can be used for opportunistic purposes. Thus, it is unclear whether bank managers use their discretion over ALL in the pre-crisis period to build a cushion against future credit losses or whether they use the discretion over these reserves to manage earnings opportunistically. To answer this question, we examine the relationships between abnormal ALL and benchmark-beating behavior (loss avoidance and just meeting or beating the prior year's earnings). ${ }^{3}$ If bank managers use abnormal ALL in the pre-crisis period to build a cushion against future credit losses, then we are unlikely to find a negative relationship between abnormal ALL and benchmark-beating behavior. However, if bank managers use their discretion over these reserves opportunistically to achieve financial reporting objectives, we are likely to find a positive relationship between abnormal ALL and benchmark-beating behavior.

Our study can also be viewed as examining how managers use their discretion in estimating the ALL, in particular whether managers use their discretion for opportunistic or efficiency reasons. If managers use their discretion to build up reserves as a cushion against future shocks, then the abnormal ALL will be negatively related to bank failure during the crisis period. Alternatively, if managers use their discretion opportunistically, then the abnormal ALL will be positively related to earnings management during the pre-crisis period.

\footnotetext{
${ }^{3}$ Another commonly used earnings benchmark is just meeting or beating analysts' forecasts (Brown and Caylor 2005). We do not employ this earnings benchmark because approximately $96 \%$ of our sample consists of private banks.
} 
A large body of accounting and finance research in the Asia Pacific region has addressed issues related to the recent global financial crisis (GFC) including risk management and fair value accounting. ${ }^{4}$ In particular, fair value accounting is studied as a contributing factor for the GFC through pro-cyclical asset value swings (Stevenson 2012). Our focus is on ALL, which is one of the largest accruals for banks. The proposed change from the incurred loss to the expected loss model for loan loss accounting by IASB will affect all countries that follow IFRS accounting standards, including many countries in the Asia Pacific region. Given this, our research will be of interest to policy makers and regulators in the region.

We use accounting data on private and public banks from the Commercial Bank Data quarterly call reports that are available from the Federal Reserve Bank of Chicago to empirically investigate these questions. Following prior research (Beck and Narayanamoorthy 2013) and using all available data from 2000 to 2006, we estimate abnormal ALL as residuals from annual cross-sectional regression of ALL on loan charge-offs, non-performing loans, homogeneous loans (i.e., the sum of individual non-mortgage loans and 1-4 family residential loans), commercial loans, size, Tier 1 capital ratio, growth in total loans, and earnings before taxes and loan loss provisions. We first test the relationship between abnormal ALL at the end of 2006 (just prior to the onset of the financial crisis) and bank failure from 2007 to 2010. We then study the relationship between abnormal ALL and bank risk taking during the pre-crisis period (i.e., 2000-2006). ${ }^{5}$ Lastly, we examine the relationship between abnormal ALL and several measures of earnings management during the pre-crisis period.

\footnotetext{
${ }^{4}$ Please see Benson et al. (2014a, 2014b) for a review of accounting and finance research in the Asia Pacific region.

${ }^{5}$ It is generally accepted that the financial crisis started in the later part of 2007 (Ryan 2008; Erkens et al. 2012). According to the National Bureau of Economic Research (NBER) in the U.S., the banking crisis started in the third quarter of 2007. Therefore, we define the pre-crisis period as 2000-2006.
} 
We report several key findings. First, abnormal ALL in the pre-crisis period has a strong negative relationship with the probability of bank failure during the crisis period. This result is both statistically and economically significant. Second, abnormal ALL is negatively related to two traditional accounting measures of bank risk taking — volatility of net interest margin and volatility of earnings — in the pre-crisis period. ${ }^{6}$ Third, in tests related to earnings management to meet or beat earnings benchmarks, we find that abnormal ALL is unrelated to loss avoidance and to just meeting or beating the prior year's earnings. These results hold for multiple measures of bandwidths as benchmarks.

An alternative explanation for our finding is that only the strong banks build loan loss reserves during the pre-crisis period and, consequently, their stability during the crisis period is not surprising. To rule out this alternative explanation, we follow Beck and Narayanamoorthy (2013) and classify banks in the lower (upper) half of the distribution of Tier 1 capital in 2006 as weak (strong) banks and estimate the failed bank regressions and risk regressions separately for each of these two subsamples. The untabulated results for both subsamples are consistent with our findings for the full sample, indicating that bank strength in the pre-crisis period, based on the capital ratio, does not alter the documented negative associations between abnormal ALL and bank failure and risk taking.

The main contribution of our study is that it provides evidence on the policy-relevant question of whether allowing discretion in the estimation of ALL is beneficial for risk management (i.e., as a cushion against future credit losses) or is used primarily for opportunistic earnings management. We also use the recent financial crisis as a setting for examining whether building of reserves through abnormal ALL in the period prior to the financial crisis is a good

\footnotetext{
${ }^{6}$ These are commonly used accounting risk measures in banking research (e.g., Laeven and Levine 2009; Houston et al. 2010; Kanagaretnam et al. 2014).
} 
indicator of bank stability during the crisis. Our results inform policy makers and accounting standard setters on banks' use of accounting discretion as a means to build a cushion against future credit losses as they transition from the incurred loss model to the expected loss model for loan loss accounting.

The rest of this paper is organized as follows. We discuss related research and develop our predictions on the effects of abnormal ALL on bank risk taking and crisis period performance in the next section. We present the research design and describe the data in section three, discuss the results in section four and provide our conclusions in the final section.

\section{Research Background and Hypotheses}

Recent literature has examined factors that affect the likelihood of bank failure and financial trouble. For example, Cole and White (2012) examine whether standard proxies for CAMELS ratings estimated from 2004 to 2008 predict bank failures in 2009. Their results indicate that capital adequacy, asset quality, earnings, and liquidity are key factors in assessing the probability of bankruptcy. Jin et al. (2011) examine whether audit quality and accounting variables measured in 2006 predict subsequent bank failures in 2007 and later. The accounting variables

include balance sheet strength (Tier 1 capital ratio), quality of loans and loan mix (level of nonperforming loans, growth in various loan categories, and loan portfolio mix), and financial reporting discretion (loan loss provisions). The audit quality variables are auditor type and auditor specialization. For troubled banks, they identify six elements that can reliably predict bank failure: auditor type, auditor industry specialization, Tier 1 capital ratio, proportion of securitized loans, growth in loans, and loan mix. We contribute to this literature by providing 
new evidence on whether and how pre-crisis period managerial discretion over loan loss allowance relates to bank risk taking and bank distress during the crisis period.

Conservative accounting practices in banks aid early warning systems by accelerating the recognition of nonperforming loans on the income statement (through loan loss provisions) and the balance sheet (through loan loss allowance). This is consistent with the conclusions of Dugan (2009), who states that banking supervisors like loan loss reserves which, when used as intended, allow banks to recognize an estimated loss on a loan or portfolio of loans when the loss becomes likely, well before the amount of the loss can be determined with precision and is actually charged off. Thus, banks can be realistic about recognizing and dealing with credit problems early, when times are good, by building up a large "war chest” of loan loss reserves.

We argue that abnormal ALL is related to pre-crisis-period risk taking and crisis-period performance. Prior literature notes that accounting practices do not exist in a vacuum; rather, good accounting policies are part of a system of good governance mechanisms and corporate policies. In our context, discretion over loan loss allowance might have a direct impact on lending behavior, loan volumes, and the selection of borrowers. According to Lim et al. (2014), loan officers adjust their lending behavior to more conservative bank loan loss accounting by being more prudent, as loan officers are driven to meet profitability targets (net of loan loss provisions); thus, more conservative loan loss accounting practices will have a direct effect on loan officers’ performance evaluations.

From a regulatory supervision perspective, more timely recognition of credit losses and the building of reserves to cover potential future losses directly affect profitability and capital ratios, which in turn could constrain growth in risky loan portfolios during credit expansion periods. Faster recognition of credit losses and reserve building could also determine the 
intensity of monitoring by regulators because profitability and capital ratios are two measures that regulators use to identify troubled banks. For example, because the CAMELS rating system used by regulators in the United States to assess the health of individual banks and identify troubled banks is primarily based on accounting numbers from regulatory filings, the level of accounting conservatism through loan loss reserves could directly affect the ability of banks to take excessive risk. Given this, we expect banks that are more conservative in their loan loss accounting to have a lower likelihood of failure in the crisis period due to lower risk taking in the pre-crisis period as well as having a larger cushion against which to write-off their loan losses during the crisis period.

Based on the discussion above, we posit the following (in null form):

H1a: Abnormal ALL in the pre-crisis period is unrelated to bank stability in the crisis period.

H1b: Abnormal ALL in the pre-crisis period is unrelated to bank risk-taking in the precrisis period.

Prior literature has also documented that managers use their discretion in estimating loan loss provisions for opportunistic reasons, such as meeting or beating a benchmark (Beatty et al. 2002; Kanagaretnam et al. 2010b), and increasing income (Kanagaretnam et al. 2010a). In particular, Beatty et al. (2002) and Kanagaretnam et al. (2010b) report that bank managers have incentives to manage earnings for benchmark beating, such as avoiding small losses and just meeting or beating the prior year's earnings. Both the incentive to engage in opportunistic earnings management using loan loss accounting and the prior evidence documenting such behavior are in direct conflict with the goal of transparency in banks' financial reporting. In 
particular, using excess loan loss reserves to manage earnings is considered undesirable by both regulators and standard setters.

However, it is unclear whether bank managers use abnormal ALL to manage earnings opportunistically. To answer this question, we examine the relationship between abnormal ALL and benchmark-beating behavior (loss avoidance and just meeting or beating the prior year's earnings) in the pre-crisis period. If bank managers use abnormal ALL in the pre-crisis period to build a cushion against future credit losses, then we are unlikely to find an association between abnormal ALL and benchmark beating. However, if bank managers use these reserves opportunistically to achieve financial reporting objectives, then we should find a positive association between abnormal ALL and benchmark-beating behavior.

Based on the discussion above, we posit the following (in null form):

H2: Abnormal ALL is unrelated to bank benchmark beating.

\section{Sample Selection}

We obtain accounting data on private and public banks from the Commercial Bank Data quarterly call reports available from the Federal Reserve Bank of Chicago. We construct annual measures of the variables of interest from quarterly data. ${ }^{7}$ We identify two sets of bank samples for our main tests: a sample of banks for the failed banks' regressions and a sample of banks for the risk regressions. The sample for the failed banks' tests includes 5,253 banks at the end of

\footnotetext{
${ }^{7}$ We have a total of 50,986 bank-year observations from Call Reports with necessary variables to compute the abnormal allowance for loan and lease losses during the 2000-2006 period. We then use the calculated abnormal allowance for loan and lease losses from the first-stage regression for each bank-year in the failed banks' regressions and risk regressions.
} 
2006. The sample for the risk regressions includes 6,549 banks that have average annual data for 2000-2006. ${ }^{8}$

Panel A of Table 1 reports descriptive statistics for the variables used in the estimation of abnormal ALL. We report the means, medians, and standard deviations of the variables for 50,986 bank-years from 2000 to 2006. The mean of $A L L$ is 0.014 and its standard deviation is 0.007. The mean and standard deviation of $A L L$ for our sample are very similar to the corresponding mean and standard deviation of 0.0139 and 0.0072 , respectively, reported by Beck and Narayanamoorthy (2013) for the period 2001-2004.

Panel B of Table 1 reports descriptive statistics for the variables used in the failed banks regressions. We include the means, medians, and standard deviations of the variables for 5,253 bank-years at the end of 2006. Approximately 5.2\% of the sample banks failed between 2007 and 2010. Panel C of Table 1 reports descriptive statistics for the variables used in the risk regressions. We include the means, medians, and standard deviations of the average of annual data for the period from 2000 to 2006. The mean volatility of interest margin (VOL_INTEREST_MARGIN) and mean volatility of earnings before taxes and loan and lease loss provisions (VOL_EARNINGS) are 0.019 and 0.020 , respectively.

\section{[Insert Table 1 About Here]}

\section{Results}

\section{Abnormal ALL}

We follow Beck and Narayanamoorthy (2013) and estimate Eq. (1) to compute the abnormal ALL from 2000 to 2006. ${ }^{9}$ However, unlike Beck and Narayanamoorthy (2013) who employ a

\footnotetext{
${ }^{8}$ We require at least four bank-year observations for each bank during the 2000-2006 period to calculate the bank's volatility of net interest margin and volatility of earnings before taxes and LLP for the risk regressions.
} 
pooled cross-sectional estimation approach, we estimate Eq. (1) using OLS in annual crosssections and also include a measure of bank performance.

$$
\begin{aligned}
A L L= & \beta_{0}+\beta_{1} C H O+\beta_{2} N P L+\beta_{3} H O M+\beta_{4} C O M+\beta_{5} S I Z E+\beta_{6} C A P R A T I O+\beta_{7} \text { GLOANS } \\
& +\beta_{8} E B T P+e
\end{aligned}
$$

where $A L L$ is the allowance for loan and lease losses scaled by total loans; $C H O$ is loan chargeoffs scaled by total loans; NPL is non-performing loans scaled by total loans; HOM is individual non-mortgage loans plus 1-4 family residential loans divided by total loans; COM is commercial loans divided by total loans; SIZE is the natural logarithm of total assets; CAPRATIO is Tier 1 capital divided by risk-weighted assets; GLOANS is growth in total loans divided by beginning total loans; and EBTP is net earnings before taxes and loan loss provisions divided by total loans. The residuals from Eq. (1) are the abnormal component of ALL, referred to as AALL.

Table 2 reports the first-stage OLS estimation results for Eq. (1). The coefficients on CHO and NPL are positive and significant at the $1 \%$ level ( $t$-value $=26.21$ and 20.31, respectively), indicating that $A L L$ is positively related to loan charge-offs and non-performing loans. These results are consistent with the findings reported in Table 2, Panel A of Beck and Narayanamoorthy (2013). The coefficient on $H O M$ is negative and significant at the $1 \%$ level ( $t$ value $=-10.33$ ), indicating that $A L L$ is negatively related to homogeneous loans (individual loans plus 1-4 family residential loans). We also find that $A L L$ is negatively associated with total assets (SIZE) and positively associated with Tier 1 capital ratio (CAPRATIO), growth in total loans (GLOANS), and bank performance $(E B T P)$.

\section{[Insert Table 2 About Here]}

\footnotetext{
${ }^{9}$ We estimated the OLS regression with clustered standard errors to account for potential serial and cross-sectional correlations (Rogers 1993; Williams 2000; Petersen 2009).
} 


\section{Relationship between Failed Banks and Abnormal ALL}

We estimate Eq. (2) to investigate the impact of abnormal ALL on the probability of bank failure. We use the following logistic model, which closely follows Beltratti and Stulz (2012) and Erkens et al. (2012):

$$
\begin{aligned}
F B=\beta_{0} & +\beta_{1} \text { ABNORMAL_ALL }+\beta_{2} \text { CAPRATIO }+\beta_{3} N P L+\beta_{4} G C O M+\beta_{5} G R E \\
& +\beta_{6} \text { GLOANS }+\beta_{7} \text { SIZE }+\beta_{8} \text { PUBLIC }+\beta_{9} \text { REGION } 2+\beta_{10} \text { REGION3 } \\
& +\beta_{11} \text { REGION }+e
\end{aligned}
$$

where $F B$ is an indicator variable that equals 1 if the bank failed between 2007 and 2010, and 0 otherwise, and $A B N O R M A L_{-} A L L$ represents abnormal loan loss allowance, which is proxied by two variables: AALL1 and RAALL1. AALL1 equals annual abnormal ALL at the end of 2006 and RAALL1 equals ranked AALL1. ${ }^{10}$ CAPRATIO is Tier 1 capital scaled by risk-weighted assets, $N P L$ is non-performing loans scaled by total loans, GCOM is growth in commercial loans scaled by total loans, GRE is growth in real estate loans scaled by total loans, GLOANS is growth in total loans scaled by total loans, SIZE is the natural logarithm of total assets, and PUBLIC is an indicator variable that equals 1 if the bank is a public bank, and 0 otherwise. Following Ng and Roychowdhury (2014), we include three geographical indicator variables in Eq. (2) to control for potential differences related to heterogeneous regional characteristics. REGION2 is an indicator variable that equals 1 if a bank is in the Midwestern region, and 0 otherwise. REGION3 and REGION4 are defined analogously for the Southern and Western regions, respectively. By construction, the Northeastern region is the benchmark region.

Table 3 reports the estimation results of Eq. (2). Of interest are the coefficients on AALL1 and RAALL1, which indicate the difference in the probability of bank failure among banks with

\footnotetext{
${ }^{10}$ We rank AALL1 using the following procedure. We first rank $A A L L 1$ from 1 to the total number of observations and then scale each ranked number by 10,000.
} 
different levels of abnormal ALL. We expect a negative coefficient on AALL1 and RAALL1, because banks that take less risk in the pre-crisis period and have a larger cushion to write-off their loan losses have a lower probability of failure. We report the coefficient estimate, followed by the Wald statistics in parentheses.

Column (1) shows that the coefficient on AALL1 is negative and significant at the $5 \%$ level (Wald chi-square $=5.09$ ), and Column (2) shows that the coefficient on RAALL1 is negative and significant at the $5 \%$ level (Wald chi-square $=5.77$ ). These results indicate that abnormal ALL is negatively associated with the probability of bank failure. Overall, the evidence rejects H1a and indicates that banks with higher abnormal ALL have a lower probability of failure during the crisis period than banks with lower abnormal ALL. ${ }^{11}$

With regard to the control variables, both columns show that the coefficients on CAPRATIO are negative and significant at the $1 \%$ level. This result is consistent with the prediction that failed banks have lower Tier 1 capital ratios. The coefficients on NPL are positive and significant at the $1 \%$ level, a finding consistent with our prediction that failed banks have a higher percentage of non-performing loans. The coefficients on GLOANS are significantly positive, indicating that failed banks had higher growth rates in total loans than healthy banks during the pre-crisis period.

\section{[Insert Table 3 About Here]}

\section{Relationship between Bank Risk Taking and Abnormal ALL}

We next examine whether managerial discretion through abnormal ALL is related to bank risk taking. We use two proxies to measure bank risk taking. The first proxy is the standard deviation

\footnotetext{
${ }^{11}$ We calculate the marginal effect to show the economic significance of the main results. If the abnormal allowance for loan and lease losses (AALL1) increases from $0 \%$ (the mean and median) to $0.2 \%(\mathrm{Q} 3)$ of total loans, the reduction in probability of bank failure is $4.25 \%$.
} 
of net interest margin (interest revenue net of interest expense) divided by the total loans during the 2000-2006 period. Given that net interest margin is a key performance measure of a bank's core business (i.e., lending), its standard deviation measures the volatility of the bank's core business performance. A riskier lending strategy will likely lead to more volatile net interest margin. The second proxy is the standard deviation of earnings before taxes and loan and lease loss provisions divided by total loans during the 2000-2006 period. ${ }^{12}$ The volatility of earnings before taxes and loan and lease loss provisions reflects the volatility of a bank's risky investments and operations.

We estimate the following model using OLS (at the individual bank level) to test the impact of abnormal ALL on bank risk taking:

$$
\begin{aligned}
\text { RISK }=\beta_{0} & +\beta_{1} \text { ABNORMAL_ALL }+\beta_{2} \text { ASIZE }+\beta_{3} A N P L+\beta_{4} A C H L O A N S+\beta_{5} P U B L I C \\
& +\beta_{6} \text { REGION } 2+\beta_{7} \text { REGION3 }+\beta_{8} \text { REGION } 4+\varepsilon
\end{aligned}
$$

where RISK is either the standard deviation of net interest margin scaled by total loans (VOL_INTEREST_MARGIN) during the 2000-2006 period or standard deviation of earnings before taxes and loan and lease losses provision scaled by total loans (VOL_EARNINGS) during the 2000-2006 period. ABNORMAL_ALL is proxied by two variables: AALL2 and RAALL2. AALL2 equals average abnormal ALL from 2000 to 2006 and RAALL2 equals ranked AALL2. ${ }^{13}$ ASIZE is the average natural logarithm of total assets from 2000 to 2006, ANPL is the annual average non-performing loans scaled by total loans between 2000 and 2006, and ACHLOANS is the average growth in total loans scaled by beginning total loans during the 2000-2006 period.

\footnotetext{
${ }^{12}$ By using earnings before loan and lease losses provisions, we reduce the impact of earnings management through loan and lease losses provisions on our risk measure.

${ }^{13}$ We rank AALL2 using the following procedure. For each year, from 2000 to 2006, we rank AALL2 from 1 to the total number of observations. We then calculate the annual average rank from 2000 to 2006 for each bank and scale each annual average ranking by 10,000 .
} 
We expect the coefficient on $A B N O R M A L_{-} A L L$ in Eq. (3) to be negative because the timely recognition of credit losses and building of reserves to cover potential future losses will directly affect profitability and capital ratios, which in turn will constrain growth in risky loan portfolios during credit expansion periods. Profitability and capital ratios could also determine the intensity of monitoring by regulators as these ratios are two of the measures used by regulators to identify troubled banks. In Table 4, Columns (1) and (3) present the results with volatility of net interest margin (VOL_INTEREST_MARGIN) as the dependent variable, and Columns (2) and (4) present the results with volatility of net earnings before taxes and provisions for loan and lease losses (VOL_EARNINGS) as the dependent variable. Of interest are the coefficients on $A A L L 2$ and $R A A L L 2$, which indicate the change in risk taking when there is a change in annual average abnormal ALL. For the variables $A A L L 2$ and $R A A L L 2$, we report the regression coefficients, followed by the $t$-statistics in parentheses.

Our results indicate that banks that follow more conservative accounting practices related to ALL exhibit less risk-taking behavior, as reflected by a lower volatility of net interest margin and lower volatility of earnings. More precisely, Columns (1) and (2) show that the coefficients on $A A L L 2$ are negative and significant at the $1 \%$ level ( $t$-value $=-7.98$ and -5.71 , respectively). Similarly, Columns (3) and (4) show that the coefficients on RAALL2 are negative and significant at the $1 \%$ level ( $t$-value $=-2.92$ and -2.93 , respectively). Overall, the evidence rejects H1b and indicates that banks with higher average abnormal ALL exhibit lower risk-taking behavior during the pre-crisis period than banks with lower average abnormal ALL. These results confirm our prediction that banks with more conservative accounting practices engage in less risk taking during the pre-crisis period, possibly due to higher financial reporting quality, which facilitates more prompt identification and correction of financial trouble both internally 
(for example, by internal governance mechanisms) and externally (for example, by external regulators). With respect to the control variables, we find that the volatility of the net interest margin is positively associated with average assets and average non-performing loans, whereas the volatility of earnings is negatively associated with average growth in total loans.

\section{[Insert Table 4 About Here]}

\section{Relationship between Abnormal ALL and Earnings Management}

Next, we use the prior year's abnormal ALL and examine its association with the current year's earnings management behavior. We estimate the following logistic regression to test the relation between abnormal ALL on banks' earnings management behavior, using annual data from 2001 to 2006: ${ }^{14}$

$$
\begin{aligned}
E M= & \beta_{0}+\beta_{1} \text { ABNORMAL_ALL }+\beta_{2} \text { SIZE }+\beta_{3} \text { GROWTH }+\beta_{4} \text { LOANS }+\beta_{5} \\
& \text { SCASH_FLOW }+ \text { YEAR FIXEDEFFECTS }+\varepsilon
\end{aligned}
$$

where $E M$ is proxied by LOSS_AVOID and JMBE.LOSS_AVOID1 (LOSS_AVOID2) equals 1 if the bank has a small ROA in the interval between 0 and 0.0005 (0.0002), and 0 otherwise; $J M B E 1$ ( $J M B E 2)$ equals 1 if the bank has a change in ROA from year $t-1$ to year $t$ in the interval between 0 and $0.0005(0.0002)$, and 0 otherwise. $A B N O R M A L_{-} A L L$ is proxied by the two variables: $A A L L 3$ and $R A A L L 3$. AALL3 equals the prior year's abnormal ALL; RAALL3 equals ranked $A A L L 3 .{ }^{15}$ SIZE is the natural logarithm of total assets, GROWTH is annual change in total assets scaled by beginning total assets, LOANS is total loans scaled by total assets, and $\triangle C A S H \_F L O W$ is annual change in cash flows (income before taxes and loan loss provisions) scaled by beginning total assets.

\footnotetext{
${ }^{14}$ Our annual data for estimating Eq. (4) are limited to the period from 2001 to 2006 . We cluster by banks.

${ }^{15}$ We rank $A A L L 3$ using the following procedure. We first rank $A A L L 3$ from 1 to the total number of observations and then scale each ranked number by 10,000.
} 
There are two viable competing explanations for the relationship between accounting conservatism and earnings management. The common belief is that firms use the allowance for loan losses as a cookie jar reserve on the balance sheet in order to reduce future loan loss expenses and increase income in future periods. Thus, abnormal ALL is likely to be positively associated with earnings management behavior. For example, Jackson and Liu (2010) find a significant and positive association between the accounting conservatism measure (i.e., the allowance for uncollectible accounts) and the earnings management measure (i.e., the probability of income-increasing bad debt expense) among industrial firms. They conclude that accounting conservatism accentuates the extent to which firms manage earnings. An alternative explanation is that banks with more conservative financial reporting use the allowance for loan losses as a risk management tool. Compared to banks that inflate their profits by under-reserving for loan and lease losses, more conservative banks report lower profitability and capital ratios, which likely subject them to higher monitoring by regulators. This explanation implies that more conservative banks are less likely to manipulate their reported earnings. Given these two competing explanations, we do not predict the direction of the relationship between abnormal ALL and earnings management during the pre-crisis period (i.e., 2001-2006).

Panel A of Table 5 presents the Eq. (4) estimation results for the two earnings management measures, LOSS_AVOID1 and LOSS_AVOID2. The coefficients on AALL3 and RAALL3 are not significant, even at the $10 \%$ level. Panel $\mathrm{B}$ of Table 5 shows the logistic regression estimation results for the earnings management measures $J M B E 1$ and $J M B E 2$. Once again, the coefficients on $A A L L 3$ and $R A A L L 3$ are not significant at the $10 \%$ level. With respect to the control variables, in Panel A, we find that banks' loss avoidance behavior is negatively associated with total assets, but positively associated with the percentage growth in total assets. 
However, in Panel B, we find that, unlike smaller banks and higher growth banks, larger banks and lower growth banks tend to just meet or beat the previous year's ROA. In summary, consistent with H2, our evidence indicates that banks do not use abnormal ALL to manage their earnings to meet or beat earnings benchmarks.

\section{[Insert Table 5 About Here]}

\section{Sensitivity Tests}

We conduct four sensitivity tests: 1) Weak and strong bank subsamples; 2) Subsamples of public and private banks; 3) Subsamples based on banks subject FDIC internal control requirements; and 4) Check whether the results hold for just the positive abnormal ALL (half the sample). For brevity we provide only a brief description of the results.

An alternate explanation for our finding is that only the strong banks build abnormal ALL during the pre-crisis period and, therefore, their financial stability during the crisis period is not surprising. To rule out this alternative explanation, we follow Beck and Narayanamoorthy (2013) and classify banks in the upper (lower) half of the distribution of Tier 1 capital ratio as strong (weak) banks. We estimate the first stage regression (Eq. 1) annually for the strong and the weak bank subsamples, and use the residuals as our estimates of abnormal ALL. We then estimate Eq. (2) and (3) for the full sample and also for the strong/weak bank subsamples. We find that abnormal ALL is significantly and negatively associated with bank failure at the $5 \%$ level for the full sample and the strong bank subsample and at the $1 \%$ level for the weak bank subsample. We find that abnormal ALL is significantly and negatively associated with our two risk measures (volatility of net interest margin and volatility of earnings before taxes and provisions) at the $1 \%$ level for the full sample and both subsamples, indicating that bank strength in the pre-crisis period, based on the capital ratio, does not alter the documented negative associations between 
abnormal ALL and bank failure and risk taking. We also find that abnormal ALL is not correlated with our earnings management measures (loss avoidance and just-meet-or-beat earnings benchmarks) at conventional levels. The sensitivity test results are consistent with our main findings.

In the second sensitivity test, we examine whether our results hold for subsamples of public and private banks. We estimate Eq. (2) and (3) separately for the public and the private bank subsamples. We find that abnormal ALL is significantly and negatively associated with bank failure at the $5 \%$ level for both the public and the private bank subsamples, indicating that whether the bank is publicly traded or not does not alter the documented negative association between abnormal ALL and bank failure. We find that abnormal ALL is significantly and negatively associated with our two risk measures (volatility of net interest margin and volatility of earnings before taxes and provisions) at the $1 \%$ level for the private bank subsample and is negatively but not significantly associated with these risk measures for the public bank subsample. We find that in both public and private bank subsamples, abnormal ALL is not associated with our earnings management measures (loss avoidance and just-meet-or-beat earnings benchmarks) at conventional levels. The sensitivity test results are consistent with our main findings.

In the third sensitivity test, we examine whether the FDICIA internal control reporting requirement has an effect on the association between abnormal ALL and bank failure and bank risk taking. We classify the sample into two subsamples: FDICIA and non-FDICIA. The FDICIA subsample consists of banks whose total assets exceed \$500 million from 2000 to 2004 and exceed \$1 billion in 2005 and 2006. The non-FDICIA subsample consists of banks that are not included in the FDICIA subsample. The FDICIA banks are subject to the FDICIA internal 
control requirements whereas the non-FDICIA banks are not. We find that for the FDICIA and the non-FDICIA subsamples, abnormal ALL is significantly and negatively associated with bank failure at the $1 \%$ and $5 \%$ level, respectively. Additionally, abnormal ALL is significantly negatively associated with our two risk measures at the $1 \%$ level for both subsamples. We also find that abnormal ALL is not associated with our earnings management measures at conventional levels. These sensitivity test results are consistent with our main findings.

Finally, we re-estimate Eq. (2) and (3) to check whether the results hold for positive abnormal ALL banks (i.e., the sample that include those banks that have above normal reserves). We find that abnormal ALL is negatively associated with bank failure at the $5 \%$ level for positive abnormal ALL banks and negatively associated with the volatility of interest margin and the volatility of earnings before taxes and provisions at the $5 \%$ and $1 \%$ level, respectively. In addition, abnormal ALL is not reliably associated with our earnings management measures. These results are consistent with our main findings.

\section{Conclusions}

The primary research questions addressed in this study are whether and how managers' discretion in estimating the allowance for loan and lease losses influences bank stability in the crisis period and bank risk taking during the pre-crisis period. In additional tests, we explore the relationship between abnormal ALL and opportunistic earnings management to meet or beat earnings benchmarks.

Our main contribution is to document that accounting discretion in estimating ALL is predominantly used as a risk management vehicle (i.e., as a cushion against future credit losses) rather than an earnings management tool. We use the recent financial crisis as a setting for 
examining whether the use of managerial discretion over ALL in the period prior to the financial crisis is a good indicator of bank stability during the crisis. Our results show that even the limited discretion allowed under the current incurred loss model for loan loss accounting had a positive effect on bank stability during the crisis period for banks that had relatively higher abnormal ALL prior to the crisis. Our evidence also indicates that banks with higher abnormal ALL took less risk in the pre-crisis period. In additional tests of earnings management, we find that these banks did not use abnormal ALL as a tool to meet or beat earnings benchmarks. These results hold for both strong and weak banks as well as for public banks and smaller private banks. Our results inform policy makers and accounting standard setters on banks' use of accounting discretion as a means to build a cushion against future credit losses rather than as an earnings management tool as they transition from the incurred loss model to the expected loss model for loan loss accounting. 


\section{References}

Basel Committee on Banking Supervision, 2011. Statement on Financial Instruments, July 19.

Beatty, A., Ke, B., and K. Petroni. 2002. Differential Earnings Management to Avoid Earnings Declines and Losses Across Publicly and Privately-Held Banks. The Accounting Review 77 (3): 547-570.

Beck, P.J., and G.S. Narayanamoorthy. 2013. Did the SEC Impact Banks' Loan Loss Reserve Policies and their Informativeness? Journal of Accounting and Economics 56 (2-3): 42-65.

Beltratti, A., and R.M. Stulz. 2012. The Credit Crisis around the Globe: Why Did Some Banks Perform Better? Journal of Financial Economics 105: 1-17.

Benson, K., Clarkson, P., Smith, T. and I. Tutticci. 2014a. A Review of Accounting Research in the Asia Pacific Region, forthcoming Australian Journal of Management.

Benson, K., Faff, R., and T. Smith. 2014b. Fifty years of finance research in the Asia Pacific Basin. Accounting \& Finance 54 (2): 335-363.

Brown, L.D., and M.L. Caylor. 2005. A Temporal Analysis of Quarterly Earnings Surprises Thresholds Propensities and Valuation Consequences. The Accounting Review 80 (2): 423440.

Bushman, R.M. and C.D. Williams. 2012. Accounting Discretion, Loan Loss Provisioning, and Discipline of Banks' Risk-Taking. Journal of Accounting and Economics 54 (1): 1-18.

Cheng, Q., Warfield, T., and M. Ye. 2011. Equity Incentives and Earnings Management: Evidence from the Banking Industry. Journal of Accounting, Auditing \& Finance 26 (2): 317-349.

Cole, R.A., and L.J. White. 2012. Déjà Vu All Over Again: The Causes of U.S. Commercial Bank Failures This Time Around. Journal of Financial Services Research 42: 5-29.

Collins, J.H., Shackelford, D.A., and J.M. Wahlen. 1995. Bank Differences in the Coordination of Regulatory Capital, Earnings, and Taxes. Journal of Accounting Research 33 (2): 263291.

Dahl, D. 2013. Bank Audit Practices and Loan Loss Provisioning. Journal of Banking \& Finance 37 (9): 3577-3584.

Dugan, J. 2009. "Loan Loss Provisioning and Pro-cyclicality.” Remarks by John C. Dugan, Comptroller of the Currency, before the Institute of International Bankers, March 2, 2009. 
Erkens, D., Hung, M., and P. Matos. 2012. Corporate Governance in the 2007-2008 Financial Crisis: Evidence from Financial Institutions Worldwide. Journal of Corporate Finance 18 (2): 389-411.

Financial Accounting Standards Board. 2011. Impairment: Three-Bucket Approach, June 13.

Financial Stability Forum. 2009. Report of the Financial Stability Forum on Addressing Procyclicality in the Financial System, Basel, April.

International Accounting Standards Board. 2011. Impairment: Three-Bucket Approach, June 13.

Jackson, S.B. and X.T. Liu. 2010. The Allowance for Uncollectible Accounts, Conservatism, and Earnings Management. Journal of Accounting Research 48 (3): 565-601.

Jin, J.Y., Kanagaretnam, K., and G.J. Lobo. 2011. Ability of Accounting and Audit Quality Variables to Predict Bank Failures During the Recent Financial Crisis. Journal of Banking \& Finance 35: 2811-2819.

Kanagaretnam, K., Lobo, G.J., and D. Yang. 2004. Joint Tests of Signaling and Income Smoothing through Bank Loan Loss Provisions. Contemporary Accounting Research 21 (4): 843-884.

Kanagaretnam, K., Krishnan, G., and G.J. Lobo. 2010a. An Empirical Analysis of Auditor Independence in the Banking Industry. The Accounting Review 85: 2011-2046.

Kanagaretnam, K., Lim, C.Y., and G.J. Lobo. 2010b. Auditor Reputation and Earnings Management: International Evidence from the Banking Industry. Journal of Banking \& Finance 34: 2318-2327.

Kanagaretnam, K., Lim, C.Y., and G.J. Lobo. 2014. Influence of National Culture on Accounting Conservatism and Risk Taking in the Banking Industry. The Accounting Review 89 (3): 1115-1149.

Laeven, L., and R. Levine. 2009. Bank Governance, Regulation and Risk Taking. Journal of Financial Economics 93: 259-275.

Lim, C.Y., Kausar, A., Lee, E., and M. Walker. 2014. Bank Accounting Conservatism, Lending Behavior and Credit Crisis. Journal of Accounting and Public Policy 33: 260-278.

Ng, J. and S. Roychowdhury. 2014. Do Loan Loss Reserves Behave Like Capital? Evidence from Recent Bank Failures. Review of Accounting Studies 19 (3): 1234-1279.

Petersen, M. 2009. Estimating Standard Errors in Finance Panel Data Sets; Comparing Approaches. Review of Financial Studies 22 (1): 435-480. 
Rogers, W. 1993. Regression Standard Errors in Clustered Samples. STATA Technical Bulletin 13: $19-23$.

Ryan, S. 2008. Accounting in and for the Subprime Crisis. The Accounting Review 83 (6): 16051638.

Ryan, S. 2011. Financial Reporting for Financial Instruments. Foundations and Trends in Accounting 6 (3-4): 187-354.

Stevenson, K.M. 2012. Financial Reporting: Hearing the GFC message? What message? Accounting \& Finance 52 (1): 9-20.

U.S. Treasury. 2009. A New Foundation: Rebuilding Financial Supervision and Regulation. Financial Regulatory Reform.

Wahlen, J.M. 1994. The Nature of Information in Commercial Bank Loan Loss Disclosures. The Accounting Review 69 (3): 455-478.

Wall, L., and T. Koch. 2000. Bank Loan-Loss Accounting: a Review of Theoretical and Empirical Evidence. Economic Review 85 (2): 1-19.

Williams, R. 2000. A Note on Robust Variance Estimation for Clustered-Correlated Data. Biometrics 56: 645-646. 
Table 1

Descriptive Statistics for Variables Used in Failed Banks Regressions and Risk Regressions

Panel A: Descriptive statistics for variables for computing abnormal allowance for loan and lease losses

\begin{tabular}{|c|c|c|c|c|c|c|}
\hline & $\mathrm{N}$ & Mean & Median & Q1 & Q3 & Standard Deviation \\
\hline \multicolumn{7}{|c|}{ Dependent Variable } \\
\hline$A L L$ & 50,986 & 0.014 & 0.012 & 0.010 & 0.015 & 0.007 \\
\hline \multicolumn{7}{|c|}{ Independent Variables } \\
\hline $\mathrm{CHO}$ & 50,986 & 0.003 & 0.001 & 0.0003 & 0.004 & 0.006 \\
\hline$N P L$ & 50,986 & 0.010 & 0.008 & 0.002 & 0.011 & 0.011 \\
\hline$H O M$ & 50,986 & 0.380 & 0.358 & 0.206 & 0.528 & 0.229 \\
\hline$C O M$ & 50,986 & 0.162 & 0.132 & 0.075 & 0.207 & 0.139 \\
\hline SIZE & 50,986 & 4.863 & 4.703 & 3.957 & 5.568 & 1.397 \\
\hline CAPRATIO & 50,986 & 0.149 & 0.144 & 0.125 & 0.165 & 0.231 \\
\hline GLOANS & 50,986 & 0.101 & 0.079 & 0.017 & 0.170 & 0.173 \\
\hline$E B T P$ & 50,986 & 0.047 & 0.046 & 0.031 & 0.063 & 0.042 \\
\hline
\end{tabular}

Panel B: Descriptive statistics for variables in the failed banks regressions

\begin{tabular}{|c|c|c|c|c|c|c|}
\hline & $\mathrm{N}$ & Mean & Median & Q1 & Q3 & Standard Deviation \\
\hline \multicolumn{7}{|c|}{ Dependent Variable } \\
\hline$F B$ & 5,253 & 0.052 & 0 & 0 & 0 & 0.222 \\
\hline \multicolumn{7}{|c|}{ Independent Variables } \\
\hline AALL1 & 5,253 & 0 & 0 & -0.003 & 0.002 & 0.005 \\
\hline RAALL1 & 5,253 & 0.270 & 0.270 & 0.135 & 0.405 & 0.156 \\
\hline CAPRATIO & 5,253 & 0.153 & 0.130 & 0.107 & 0.174 & 0.070 \\
\hline NAL & 5,253 & 0.014 & 0.010 & 0.005 & 0.019 & 0.013 \\
\hline GCOM & 5,253 & 0.008 & 0.005 & -0.003 & 0.018 & 0.025 \\
\hline GRE & 5,253 & 0.080 & 0.042 & -0.030 & 0.135 & 0.223 \\
\hline GLOANS & 5,253 & 0.103 & 0.076 & 0.020 & 0.149 & 0.148 \\
\hline SIZE & 5,253 & 5.043 & 4.933 & 4.163 & 5.767 & 1.276 \\
\hline PUBLIC & 5,253 & 0.048 & 0 & 0 & 0 & 0.213 \\
\hline REGION2 & 5,253 & 0.406 & 0 & 0 & 1.000 & 0.491 \\
\hline REGION3 & 5,253 & 0.343 & 0 & 0 & 1.000 & 0.475 \\
\hline REGION4 & 5,253 & 0.100 & 0 & 0 & 0 & 0.299 \\
\hline
\end{tabular}


Table 1 (Cont'd)

Panel C: Descriptive statistics for variables in the risk regressions

\begin{tabular}{|c|c|c|c|c|c|c|}
\hline & $\mathrm{N}$ & Mean & Median & Q1 & Q3 & Standard Deviation \\
\hline \multicolumn{7}{|l|}{ Dependent Variables } \\
\hline VOL_INTEREST_MARGIN & 6,549 & 0.019 & 0.014 & 0.010 & 0.021 & 0.017 \\
\hline$V O L E A R N I N G \bar{S}$ & 6,549 & 0.020 & 0.013 & 0.009 & 0.020 & 0.022 \\
\hline \multicolumn{7}{|l|}{ Independent Variables } \\
\hline AALL2 & 6,549 & 0 & 0 & -0.002 & 0.002 & 0.005 \\
\hline RAALL2 & 6,549 & 0.327 & 0.327 & 0.164 & 0.491 & 0.189 \\
\hline ASIZE & 6,549 & 4.872 & 4.728 & 4.020 & 5.555 & 1.292 \\
\hline$A N P L$ & 6,549 & 0.009 & 0.007 & 0.003 & 0.012 & 0.009 \\
\hline ACHLOANS & 6,549 & 0.136 & 0.084 & 0.041 & 0.156 & 0.175 \\
\hline PUBLIC & 6,549 & 0.034 & 0 & 0 & 0 & 0.181 \\
\hline REGION2 & 6,549 & 0.401 & 0 & 0 & 1.000 & 0.490 \\
\hline REGION3 & 6,549 & 0.326 & 0 & 0 & 1.000 & 0.468 \\
\hline REGION4 & 6,549 & 0.118 & 0 & 0 & 0 & 0.322 \\
\hline
\end{tabular}

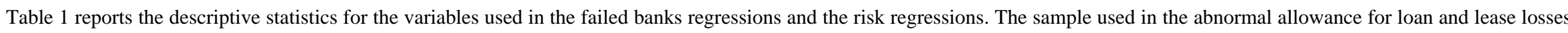

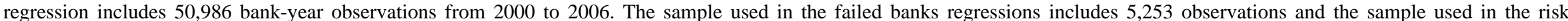

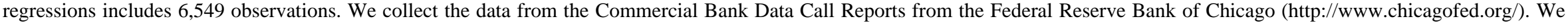
winsorize the top and bottom $1 \%$ of each continuous variable.

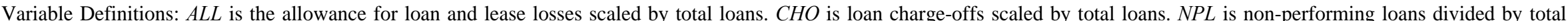

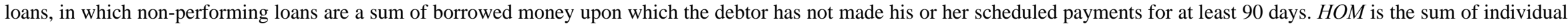

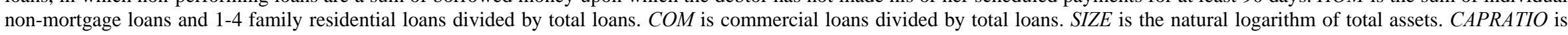

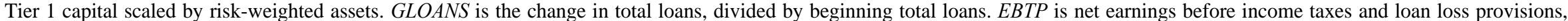

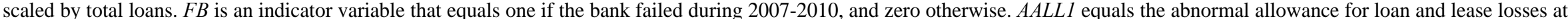

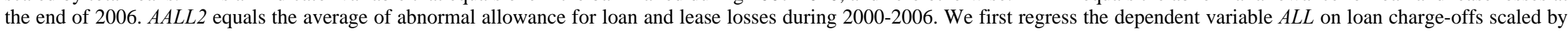

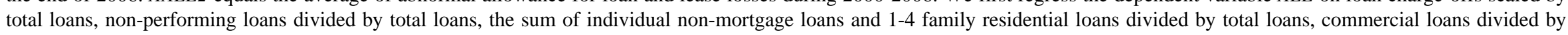

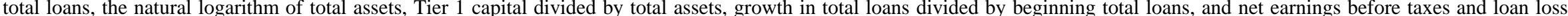

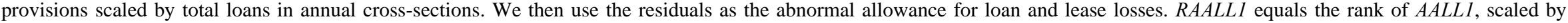

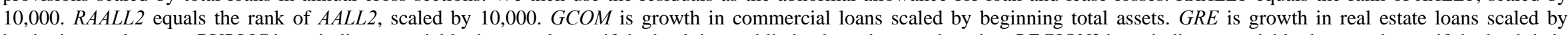

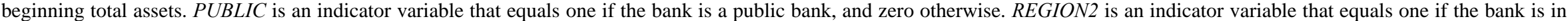

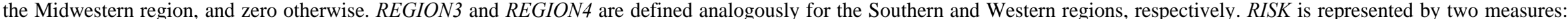

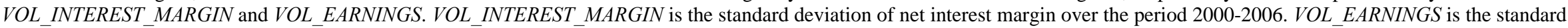

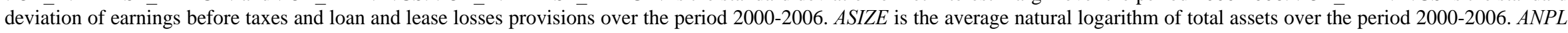

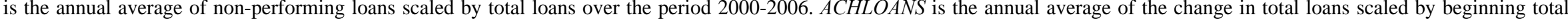
loans over the period 2000-2006. 
Table 2

First-Stage Regression for Computing Abnormal Allowance for Loan and Lease Losses

\begin{tabular}{l|c}
\hline & Dependent Variable $=A L L$ \\
\hline Variable & Coefficient \\
& $(\mathrm{t}$-value) \\
\hline Intercept & $0.010^{* * *}$ \\
& $(25.17)$ \\
\hline CHO & $0.395^{* * *}$ \\
& $(26.21)$ \\
\hline NPL & $0.125^{* * *}$ \\
& $(20.31)$ \\
\hline HOM & $-0.003^{* * *}$ \\
& $(-10.33)$ \\
\hline COM & $0.001^{* *}$ \\
& $(2.14)$ \\
\hline SIZE & $-0.0004^{* * *}$ \\
& $(-8.15)$ \\
\hline CAPRATIO & $0.021^{* * *}$ \\
& $(8.46)$ \\
\hline GLOANS & $0.0004^{* * *}$ \\
& $(3.95)$ \\
\hline EBTP & $0.046^{* * *}$ \\
\hline Adjusted-R ${ }^{2}$ & $(22.68)$ \\
\hline \# of Observations & \\
\hline
\end{tabular}

Table 2 reports the results for OLS regression on the allowance for loan and lease losses with standard errors clustered by banks. We run the regressions in annual cross-sections. We winsorize the top and bottom $1 \%$ of each continuous variable. *, **, *** indicate significance at the $10 \%, 5 \%$, and $1 \%$ levels, respectively, based on a two-tailed test.

All variables are defined in the notes to Table 1. 
Table 3

Bank Failure and Abnormal Allowance for Loan and Lease Losses

\begin{tabular}{|c|c|c|}
\hline & Dependent Variable $=F B$ & Dependent Variable $=F B$ \\
\hline Variable & $\begin{array}{c}\text { Coefficient } \\
\text { (Wald Chi-Square) } \\
\text { (1) }\end{array}$ & $\begin{array}{c}\text { Coefficient } \\
\text { (Wald Chi-Square) } \\
(2)\end{array}$ \\
\hline Intercept & $\begin{array}{c}-1.863^{* * *} \\
(24.79)\end{array}$ & $\begin{array}{c}-1.728^{* * *} \\
(20.22)\end{array}$ \\
\hline AALL1 & $\begin{array}{c}-17.525^{* *} \\
(5.09)\end{array}$ & \\
\hline RAALL1 & & $\begin{array}{c}-0.410 * * \\
(5.77)\end{array}$ \\
\hline CAPRATIO & $\begin{array}{c}-7.985 * * * \\
(11.69) \\
\end{array}$ & $\begin{array}{c}-7.983^{* * *} \\
(11.90) \\
\end{array}$ \\
\hline$N P L$ & $\begin{array}{c}14.862 * * * \\
(42.83)\end{array}$ & $\begin{array}{c}14.692^{* * *} \\
(42.22)\end{array}$ \\
\hline GCOM & $\begin{array}{l}0.005 \\
(2.57)\end{array}$ & $\begin{array}{l}0.005 \\
(2.57)\end{array}$ \\
\hline$G R E$ & $\begin{array}{c}-0.020 * \\
(3.54)\end{array}$ & $\begin{array}{c}-0.021 * \\
(3.53)\end{array}$ \\
\hline GLOANS & $\begin{array}{c}0.087 * * * \\
(17.97)\end{array}$ & $\begin{array}{c}0.088 * * * \\
(17.85)\end{array}$ \\
\hline SIZE & $\begin{array}{l}0.045 \\
(1.32) \\
\end{array}$ & $\begin{array}{l}0.047 \\
(1.43)\end{array}$ \\
\hline PUBLIC & $\begin{array}{l}0.137 \\
(0.50) \\
\end{array}$ & $\begin{array}{l}0.140 \\
(0.52) \\
\end{array}$ \\
\hline REGION2 & $\begin{array}{l}0.024 \\
(0.03)\end{array}$ & $\begin{array}{l}0.024 \\
(0.03)\end{array}$ \\
\hline REGION3 & $\begin{array}{c}0.309^{* *} \\
(5.43)\end{array}$ & $\begin{array}{c}0.312^{* *} \\
(5.55)\end{array}$ \\
\hline REGION4 & $\begin{array}{l}0.035 \\
(0.04) \\
\end{array}$ & $\begin{array}{l}0.037 \\
(0.05) \\
\end{array}$ \\
\hline Log-Likelihood & -531.3 & -531.7 \\
\hline Pseudo- $\mathrm{R}^{2}$ & 0.078 & 0.077 \\
\hline Percent Concordant & 70.7 & 70.3 \\
\hline \# of Observations & 5,253 & 5,253 \\
\hline
\end{tabular}

Table 3 reports the results for two logistic regression models with standard errors clustered by banks. We winsorize the top and bottom $1 \%$ of each continuous variable. *, **, *** indicate significance at the $10 \%, 5 \%$, and $1 \%$ levels, respectively, based on a two-tailed test.

All variables are defined in the notes to Table 1. 
Table 4

Risking-taking Behavior and Abnormal Allowance for Loan and Lease Losses

\begin{tabular}{|c|c|c|c|c|}
\hline & $\begin{array}{c}\text { Dependent Variable }= \\
\text { VOL_INTEREST_MARGIN }\end{array}$ & $\begin{array}{c}\text { Dependent Variable }= \\
\text { VOL_EARNINGS }\end{array}$ & $\begin{array}{c}\text { Dependent Variable }= \\
\text { VOL_INTEREST_MARGIN }\end{array}$ & $\begin{array}{c}\text { Dependent Variable }= \\
\text { VOL_EARNINGS }\end{array}$ \\
\hline Variable & $\begin{array}{c}\text { Coefficient } \\
\text { (t-value) } \\
(1)\end{array}$ & $\begin{array}{l}\text { Coefficient } \\
\text { (t-value) } \\
\text { (2) }\end{array}$ & $\begin{array}{c}\text { Coefficient } \\
\text { (t-value) } \\
\text { (3) }\end{array}$ & $\begin{array}{l}\text { Coefficient } \\
\text { (t-value) } \\
\text { (4) }\end{array}$ \\
\hline Intercept & $\begin{array}{l}-0.450 \\
(-1.59) \\
\end{array}$ & $\begin{array}{l}2.552^{*} \\
(1.77)\end{array}$ & $\begin{array}{l}-0.220 \\
(-0.73) \\
\end{array}$ & $\begin{array}{c}3.792 * * \\
(2.49) \\
\end{array}$ \\
\hline$A A L L 2$ & $\begin{array}{c}-92.919 * * * \\
(-7.98) \\
\end{array}$ & $\begin{array}{c}-337.871 * * * \\
(-5.71) \\
\end{array}$ & & \\
\hline RAALL2 & & & $\begin{array}{c}-0.638 * * * \\
(-2.92)\end{array}$ & $\begin{array}{c}-3.234 * * * \\
(-2.93)\end{array}$ \\
\hline$A S I Z E$ & $\begin{array}{c}0.102 * * \\
(2.21) \\
\end{array}$ & $\begin{array}{l}0.003 \\
(0.01) \\
\end{array}$ & $\begin{array}{c}0.108^{* *} \\
(2.34)\end{array}$ & $\begin{array}{l}0.038 \\
(0.16) \\
\end{array}$ \\
\hline$A N P L$ & $\begin{array}{l}13.440^{* * * *} \\
(7.04)\end{array}$ & $\begin{array}{l}12.722 \\
(1.31)\end{array}$ & $\begin{array}{c}12.626^{* * * *} \\
(6.59)\end{array}$ & $\begin{array}{l}10.024 \\
(1.03)\end{array}$ \\
\hline$A G L O A N S$ & $\begin{array}{l}-0.199 \\
(-0.62)\end{array}$ & $\begin{array}{c}-4.225^{* *} \\
(-2.57)\end{array}$ & $\begin{array}{l}-0.105 \\
(-0.32)\end{array}$ & $\begin{array}{c}-3.841^{* *} \\
(-2.33)\end{array}$ \\
\hline PUBLIC & $\begin{array}{l}-0.215 \\
(-0.64) \\
\end{array}$ & $\begin{array}{l}-0.323 \\
(-0.19) \\
\end{array}$ & $\begin{array}{l}-0.236 \\
(-0.70) \\
\end{array}$ & $\begin{array}{l}-0.355 \\
(-0.21) \\
\end{array}$ \\
\hline REGION2 & $\begin{array}{l}-0.097 \\
(-0.55)\end{array}$ & $\begin{array}{c}-2.220 * * \\
(-2.47)\end{array}$ & $\begin{array}{l}-0.062 \\
(-0.35)\end{array}$ & $\begin{array}{c}-2.121^{* *} \\
(-2.36)\end{array}$ \\
\hline REGION3 & $\begin{array}{l}0.058 \\
(0.32) \\
\end{array}$ & $\begin{array}{l}-1.630^{*} \\
(-1.78)\end{array}$ & $\begin{array}{l}0.091 \\
(0.51) \\
\end{array}$ & $\begin{array}{c}-1.528^{*} \\
(-1.67) \\
\end{array}$ \\
\hline REGION4 & $\begin{array}{l}0.086 \\
(0.38) \\
\end{array}$ & $\begin{array}{l}-0.891 \\
(-0.77) \\
\end{array}$ & $\begin{array}{l}0.081 \\
(0.36) \\
\end{array}$ & $\begin{array}{l}-0.910 \\
(-0.79) \\
\end{array}$ \\
\hline Adjusted-R ${ }^{2}$ & 0.016 & 0.006 & 0.008 & 0.002 \\
\hline \# of Observations & 6,549 & 6,549 & 6,549 & 6,549 \\
\hline
\end{tabular}

Table 4 reports the results for the OLS regression models. We winsorize the top and bottom $1 \%$ of each continuous variable. *, $* *$, $* * *$ indicate significance at the $10 \%, 5 \%$, and $1 \%$ levels, respectively, based on a two-tailed test.

All variables are defined in the notes to Table 1. 
Table 5

Earnings Management and Abnormal Allowance for Loan and Lease Losses

Panel A: Loss Avoidance Regressions

\begin{tabular}{|c|c|c|c|c|}
\hline & $\begin{array}{c}\text { Dependent Variable }= \\
\text { LOSS AVOIDI }\end{array}$ & $\begin{array}{c}\text { Dependent Variable }= \\
\text { LOSS_AVOIDI }\end{array}$ & $\begin{array}{c}\text { Dependent Variable }= \\
\text { LOSS AVOID2 }\end{array}$ & $\begin{array}{c}\text { Dependent Variable }= \\
\text { LOSS_AVOID2 }\end{array}$ \\
\hline Variable & $\begin{array}{c}\text { Coefficient } \\
\text { (Wald Chi-Square) } \\
\text { (1) }\end{array}$ & $\begin{array}{c}\text { Coefficient } \\
\text { (Wald Chi-Square) } \\
\text { (2) }\end{array}$ & $\begin{array}{c}\text { Coefficient } \\
\text { (Wald Chi-Square) } \\
\text { (3) }\end{array}$ & $\begin{array}{c}\text { Coefficient } \\
\text { (Wald Chi-Square) } \\
\text { (4) }\end{array}$ \\
\hline Intercept & $\begin{array}{c}-1.253^{* * *} \\
(11.89)\end{array}$ & $\begin{array}{c}-1.269 * * * \\
(12.83)\end{array}$ & $\begin{array}{c}-1.633^{* * *} \\
(13.74)\end{array}$ & $\begin{array}{c}-1.536 * * * \\
(12.79)\end{array}$ \\
\hline AALL3 & $\begin{array}{l}8.546 \\
(1.78) \\
\end{array}$ & & $\begin{array}{l}-6.246 \\
(0.29)\end{array}$ & \\
\hline RAALL3 & & $\begin{array}{l}0.032 \\
(0.64)\end{array}$ & & $\begin{array}{l}-0.078 \\
(1.51)\end{array}$ \\
\hline SIZE & $\begin{array}{c}-0.180 * * * \\
(24.19)\end{array}$ & $\begin{array}{c}-0.182^{* * * *} \\
(24.51)\end{array}$ & $\begin{array}{c}-0.147 * * * \\
(17.97)\end{array}$ & $\begin{array}{c}-0.145^{* * * *} \\
(16.88)\end{array}$ \\
\hline GROWTH & $\begin{array}{l}0.642^{*} \\
(3.78)\end{array}$ & $\begin{array}{l}0.635^{*} \\
(3.71)\end{array}$ & $\begin{array}{c}0.773^{* *} \\
(5.07)\end{array}$ & $\begin{array}{c}0.797 * * \\
(5.70)\end{array}$ \\
\hline LOANS & $\begin{array}{l}0.275 \\
(0.60)\end{array}$ & $\begin{array}{l}0.255 \\
(0.53)\end{array}$ & $\begin{array}{l}-0.077 \\
(0.04)\end{array}$ & $\begin{array}{l}-0.060 \\
(0.02)\end{array}$ \\
\hline$\triangle C A S H \_F L O W$ & $\begin{array}{l}-3.803 \\
(1.26)\end{array}$ & $\begin{array}{l}-3.822 \\
(1.25)\end{array}$ & $\begin{array}{l}5.426 \\
(2.10)\end{array}$ & $\begin{array}{l}5.671 \\
(2.36)\end{array}$ \\
\hline YEAR FIXED EFFECTS & YES & YES & YES & YES \\
\hline Log-Likelihood & -346.0 & -346.4 & -139.0 & -138.4 \\
\hline Pseudo- $\mathrm{R}^{2}$ & 0.042 & 0.041 & 0.060 & 0.064 \\
\hline Percent Concordant & 32.8 & 29.3 & 17.3 & 11.6 \\
\hline \# of Observations & 37,543 & 37,543 & 37,543 & 37,543 \\
\hline
\end{tabular}

Panel B: Just-Meet-or-Beat Prior Year's Earnings Regressions

\begin{tabular}{|c|c|c|c|c|}
\hline & $\begin{array}{c}\text { Dependent Variable }= \\
J M B E 1\end{array}$ & $\begin{array}{c}\text { Dependent Variable = } \\
J M B E 1\end{array}$ & $\begin{array}{c}\text { Dependent Variable }= \\
J M B E 2\end{array}$ & $\begin{array}{c}\text { Dependent Variable }= \\
J M B E 2\end{array}$ \\
\hline Variable & $\begin{array}{c}\text { Coefficient } \\
\text { (Wald Chi-Square) } \\
\text { (1) }\end{array}$ & $\begin{array}{c}\text { Coefficient } \\
\text { (Wald Chi-Square) } \\
(2)\end{array}$ & $\begin{array}{c}\text { Coefficient } \\
\text { (Wald Chi-Square) } \\
\text { (3) }\end{array}$ & $\begin{array}{c}\text { Coefficient } \\
\text { (Wald Chi-Square) } \\
(4)\end{array}$ \\
\hline Intercept & $\begin{array}{c}-2.467 * * * \\
(418.42) \\
\end{array}$ & $\begin{array}{c}-2.486 * * * \\
(419.50) \\
\end{array}$ & $\begin{array}{c}-2.562 * * * \\
(241.38) \\
\end{array}$ & $\begin{array}{l}-2.590 * * * \\
(243.51) \\
\end{array}$ \\
\hline$A A L L 3$ & $\begin{array}{l}1.739 \\
(0.66) \\
\end{array}$ & & $\begin{array}{l}2.829 \\
(0.98) \\
\end{array}$ & \\
\hline$R A A L L 3$ & & $\begin{array}{l}0.017 \\
(2.17)\end{array}$ & & $\begin{array}{l}0.023 \\
(2.16)\end{array}$ \\
\hline SIZE & $\begin{array}{l}0.052 * * * \\
(30.88)\end{array}$ & $\begin{array}{l}0.051 * * * \\
(29.92)\end{array}$ & $\begin{array}{c}0.032 * * \\
(6.61)\end{array}$ & $\begin{array}{c}0.031^{* *} \\
(6.18)\end{array}$ \\
\hline GROWTH & $\begin{array}{c}-0.378 * * * \\
(18.65)\end{array}$ & $\begin{array}{c}-0.381^{* * *} \\
(19.00)\end{array}$ & $\begin{array}{c}-0.257 * * \\
(4.74) \\
\end{array}$ & $\begin{array}{c}-0.261 * * \\
(4.90) \\
\end{array}$ \\
\hline$L O A N S$ & $\begin{array}{l}0.123 \\
(2.39) \\
\end{array}$ & $\begin{array}{l}0.121 \\
(2.30) \\
\end{array}$ & $\begin{array}{l}0.062 \\
(0.32) \\
\end{array}$ & $\begin{array}{l}0.058 \\
(0.29) \\
\end{array}$ \\
\hline$\triangle C A S H \_F L O W$ & $\begin{array}{c}-0.842 * * \\
(4.28) \\
\end{array}$ & $\begin{array}{c}-0.875 * * \\
(4.56) \\
\end{array}$ & $\begin{array}{c}-1.520^{* * *} \\
(8.55) \\
\end{array}$ & $\begin{array}{c}-1.562 * * * \\
(8.87) \\
\end{array}$ \\
\hline YEAR FIXED EFFECTS & YES & YES & YES & YES \\
\hline Log-Likelihood & -5304.9 & -5303.9 & -2575.5 & -2575.1 \\
\hline Pseudo- $\mathrm{R}^{2}$ & 0.007 & 0.007 & 0.005 & 0.005 \\
\hline Percent Concordant & 52.5 & 52.5 & 45.6 & 46.9 \\
\hline \# of Observations & 37,543 & 37,543 & 37,543 & 37,543 \\
\hline
\end{tabular}




\section{Table 5 (Cont'd)}

Table 5 reports the results for the logistic regression models with standard errors clustered by banks. We winsorize the top and bottom $1 \%$ of each continuous variable. *, **, *** indicate significance at the $10 \%, 5 \%$, and $1 \%$ levels, respectively, based on a two-tailed test.

Variable Definitions: LOSS_AVOID1 is an indicator variable that equals one if the bank has a small ROA (income before taxes scaled by total assets) in the interval between 0 and 0.0005 , and zero otherwise. LOSS_AVOID2 is an indicator variable that equals one if the bank has a small ROA (income before taxes scaled by total assets) in the interval between 0 and 0.0002 , and zero otherwise. $J M B E 1$ is an indicator variable that equals one if the bank has a change in ROA (income before taxes scaled by total assets) from year $t-1$ to year $t$ in the interval between 0 and 0.0005 , and zero otherwise. $J M B E 2$ is an indicator variable that equals one if the bank has a change in ROA (income before taxes scaled by total assets) from year $t$ - 1 to year $t$ in the interval between 0 and 0.0002, and zero otherwise. AALL3 equals the previous year's abnormal allowance for loan and lease losses. We first regress the dependent variable loan loss allowance scaled by total loans on loan charge-offs scaled by total loans, nonperforming loans divided by total loans, the sum of individual non-mortgage loans and 1-4 family residential loans divided by total loans, the commercial loans divided by total loans, the natural logarithm of total assets, the Tier 1 capital divided by total assets, the growth in total loans divided by the beginning total loans, and net earnings before income taxes and loan loss provisions scaled by total loans in annual cross-sections. We then use the residuals as the abnormal allowance for loan and lease losses. RAALL3 equals the ranking of $A A L L 3$, scaled by 10,000 . SIZE is the natural logarithm of total assets. GROWTH is the change in total assets, scaled by the beginning total assets. LOANS is total loans scaled by total assets. $\triangle C A S H \_F L O W$ is the change in cash flows (income before taxes and loan loss provisions) scaled by the beginning total assets. 